\title{
Revisiting the Specificity of PCR Primers for Diagnostics of Xanthomonas citri pv. citri by Experimental and In Silico Analyses
}

Suzy Delcourt, Christian Vernière, Claudine Boyer, and Olivier Pruvost, CIRAD, UMR PVBMT, F-97410 Saint-Pierre, La Réunion, France; Bruno Hostachy, Laboratoire de la Santé des Végétaux, Anses; and Isabelle Robène-Soustrade, CIRAD, UMR PVBMT, F-97410 Saint-Pierre, La Réunion, France

\begin{abstract}
Delcourt, S., Vernière, C., Boyer, C., Pruvost, O., Hostachy, B., and Robène-Soustrade, I. 2013. Revisiting the specificity of PCR primers for diagnostics of Xanthomonas citri pv. citri by experimental and in silico analyses. Plant Dis. 97:373-378.

Asiatic citrus canker disease, caused by Xanthomonas citri pv. citri, seriously impacts citrus production worldwide. Two pathogenic variants, $\mathrm{A}$ and $\mathrm{A}^{*} / \mathrm{A}^{\mathrm{w}}$, have been described within this pathovar. Two additional pathovars of $X$. citri with a limited geographic distribution and reduced pathogenicity, namely $X$. citri pvs. aurantifolii and bilvae, are also pathogenic to citrus and some rutaceous species. Rapid and reliable identification is required for these citrus pathogens, which are classified as a quarantine organism in citrus-producing countries. The specificity of nine polymerase chain reaction primers previously designed for the identification of $X$. citri pv. citri or citrus bacterial can-

strain collection $(n=87)$, including the two pathotypes of $X$. citri pv. citri, other genetic related or unrelated pathogenic xanthomonads, and saprophytic xanthomonads. This study gave congruent results with the original articles when testing the same strains or pathovars but the use of a broad inclusivity and exclusivity panel of strains highlighted new findings. Particularly, primers $2 / 3,4 / 7$, and KingF/R failed to provide amplification for three strains from the pathotype $\mathrm{A}^{*} / \mathrm{A}^{\mathrm{w}}$. Moreover, all pairs of primers detected at least one non-target strain. These data were supported by in silico analysis of the DNA sequences available from National Center for Biotechnology Information databases.
\end{abstract} ker strains (both pvs. citri and aurantifolii) was assayed on a large
Four xanthomonads cause two distinct disease phenotypes within the Rutaceae family, especially on the genus Citrus. Spot diseases with water-soaked lesions are induced by Xanthomonas axonopodis pv. citrumelo and $X$. citri $\mathrm{pv}$. bilvae. X. axonopodis $\mathrm{pv}$. citrumelo was mainly isolated from the rootstock citrumelo (Poncirus trifoliata $\times$ Citrus paradise; and, to a lesser extent, from grapefruit [C. paradise]) in nurseries in Florida (25). X. citri pv. bilvae was reported to be pathogenic on Aegle marmelos and Feronia elephantum, two rutaceous plants from India. X. citri pv. bilvae also expresses a host compatibility with Mexican lime (C. aurantifolia; 4,21). Two distinct pathovars, $X$. citri pv. citri and X. citri pv. aurantifolii, induce citrus bacterial canker (CBC) with similar erumpent corky lesions and are responsible for Asiatic citrus canker (ACC) and South American citrus canker, respectively $(1,24)$. These pathogens are phenotypically and genetically distinct (2). Among these, $X$. citri pv. citri has the greatest economic impact on most commercial citrus cultivars worldwide, whereas $X$. citri pv. aurantifolii is limited to South America and restricted to lime and lemon. In addition, two genetically related pathogenic variants, which differ in host range, were identified within the pathovar citri. Pathotype A (X. citri pv. citri-A) strains have a wide host range and worldwide distribution and are a well-known threat to the citrus industry. In contrast, the more recently characterized pathotype $A^{*}$ (X. citri pv. citri-A*) primarily induces canker on Mexican lime and was reported to severely impact lime production in some areas of Asia and Africa $(5,8,29)$. A third pathotype naturally infecting

Corresponding author: I. Robène-Soustrade,

E-mail: isabelle.robene@cirad.fr

S. Delcourt and C. Vernière contributed equally as first authors to this work.

* The $\boldsymbol{e}$-Xtra logo stands for "electronic extra" and indicates that four supplementary tables and two supplementary figures are available online.

Accepted for publication 2 October 2012.

http://dx.doi.org/10.1094/PDIS-04-12-0351-RE

(C) 2013 The American Phytopathological Society
Mexican lime and alemow (C. macrophylla) was described in Florida and referred to as $A^{\mathrm{w}}$ (26). However, these strains were found to be very similar to pathotype $A^{*}$ strains, which were previously reported from India (4).

Xanthomonads inducing $\mathrm{CBC}$ and, more generally, all xanthomonads pathogenic to citrus are classified as quarantine organisms in different citrus-producing countries. For instance, the European Community Directive 2000/29/EC regulates all xanthomonad strains pathogenic to citrus, and the European and Mediterranean Plant Protection Organization (EPPO) list A1 recommends regulating the $\mathrm{CBC}$-causing strains. As a consequence, citrus material exchanges are subject to severe phytosanitary regulations banning importation from contaminated areas. Consequently, huge eradication campaigns were conducted in some producing countries in order to maintain their citrus export markets $(10,20)$. Several polymerase chain reaction (PCR)-based diagnostic tools were developed with the aim of specifically detecting $X$. citri pv. citri strains $(6,7,13,19)$ or $X$. citri CBC-inducing strains (i.e., pvs. citri and aurantifolii,) $(7,11,12,17,18)$.

Recent results provided new insights into the genetic relatedness among strains within the pathovar citri and within the species $X$. citri. In particular, the $\mathrm{A}^{*} / \mathrm{A}^{\mathrm{w}}$ strains revealed a greater genetic diversity than A strains based on amplified fragment length polymorphism, insertion sequence-ligation mediated PCR, and variable numbers of tandem repeats (3). In addition, X. citri pv. bilvae was closely related to $X$. citri genomospecies but clearly differentiated from canker-causing strains (4).

The purpose of this study was to reevaluate the specificity of different PCR primers, which were designed for the detection of $X$. citri pv. citri or xanthomonads responsible for $\mathrm{CBC}$, in the light of the recent genotyping data. The specificity was assessed at different levels (CBC-inducing strains, pathovar, and pathotype) using two criteria according to the European Standard EN ISO 16140:2003: the inclusivity (i.e., the ability of the different primers to detect all strains of the target organism) and the exclusivity (i.e., the capacity to generate negative responses from an extensive range of related but non-target strains, including other Xanthomonas spp. or pathovars and supposedly saprophytic xanthomonads isolated from asymptomatic citrus). 


\section{Materials and Methods}

Bacterial strains and DNA isolation. Bacterial strains used in this study are listed in Supplementary Tables S1, S2, and S3. Our collection $(n=87)$ included $37 X$. citri pv. citri strains with different pathogenic variants (i.e., 22 strains of pathotype $A$ and 15 strains of pathotype $\left.\mathrm{A}^{*} / \mathrm{A}^{\mathrm{w}}\right) ; 11$ other Xanthomonas strains pathogenic to citrus and related hosts; 16 other pathogenic xanthomonads from the genetic subgroup 9, as defined by Vauterin et al. (28); 3 strains from additional taxons $X$. campestris pv. campestris and $X$. oryzae pv. oryzae; and 20 saprophytic Xanthomonas strains isolated from citrus in Argentina and Florida that were tentatively identified at the species level by Multi Locus Sequence Analysis (MLSA) using four gene portions, as described previously (4). The lack of pathogenicity for citrus of the supposedly saprophytic strains was checked by inoculation on Mexican lime and sweet orange 'Pineapple' plants (data not shown). Twenty-one strains have already been tested in published diagnostic protocols and served as controls.

Strains were stored at $-80^{\circ} \mathrm{C}$ on beads in cryovials (Microbank Prolab Diagnostics) or lyophilized for long-term storage. Individual strains were subcultured on yeast-peptone-glucose agar (YPGA; yeast extract at $7 \mathrm{~g} /$ liter, peptone at $7 \mathrm{~g} /$ liter, glucose at $7 \mathrm{~g} /$ liter, and agar at $18 \mathrm{~g} /$ liter; $\mathrm{pH}$ 7.2) plates at $28^{\circ} \mathrm{C}$ for $24 \mathrm{~h}$. Bacterial suspensions were prepared in sterile high-performance liquid chromatography-grade water and adjusted at approximately $1 \times 10^{8} \mathrm{CFU} / \mathrm{ml}$ by fluorometry (Labtech; Nanodrop Technologies). These suspensions were boiled for 2 min and then cooled on ice to release DNA from cells before performing PCR amplification.

PCR amplification. Information on the primers and their sequences are presented in Table 1. PCRs were performed using a GeneAmp PCR system 9700 thermocycler (Applied Biosystems). Strain IAPAR 306 was used as a positive control. Negative controls (sterile pure water instead of bacterial suspension) were systematically included. PCRs were performed at least twice in independent experiments for each of the nine primer pairs. The reaction mixtures were prepared according to the authors' instructions, with slight modifications (Supplementary Table S4). Goldstar Red Taq DNA polymerase in $75 \mathrm{mM}$ Tris- $\mathrm{HCl}, 20 \mathrm{mM}\left(\mathrm{NH}_{4}\right)_{2} \mathrm{SO}_{4}$, and

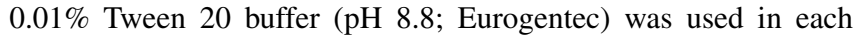
assay. Rounds of PCR for each primer pair were similar to those described in the respective publications, except for the primer pairs VM3/VM4 and KingF/R originally used in real-time PCR assays. For these primers, conventional PCR protocols were optimized, using the same annealing temperatures as for real-time PCR assays. Amplicons were separated by electrophoresis in $2 \%$ Seakem
LE agarose (FMC BioProducts), stained with ethidium bromide, and visualized with UV light.

In silico analysis. The complete sequences of some collection strains were available from the National Center for Biotechnology Information (NCBI) (named reference strains in this study). We compared the PCR responses obtained with those predicted in silico using Primer-BLAST (http://www.ncbi.nlm.nih.gov/tools/ primer-blast/): $X$. citri pv. citri strain IAPAR 306, X. axonopodis pv. citrumelo strain CFBP 3138 (= strain F1), X. oryzae pv. oryzae strain PXO99A, $X$. euvesicatoria strain 85-10 (= CFBP 5618), $X$ campestris pv. campestris strain American Type Culture Collection (ATCC) 33913 (=LMG 568), and X. citri pv. mangiferaeindicae strain LMG 941 (=CFBP 1716).

The specificity of the different primers was assayed using the different DNA sequences available on NCBI. Ninety genome sequences of Xanthomonas spp. are currently available (http:// www.ncbi.nlm.nih.gov/genomes/lproks.cgi), including 79 wholegenome shotgun sequences. The specificity of the different primers has been checked on the complete genome sequences using Primer-BLAST (July 2012). The different input parameters were (i) organism: Xanthomonas (taxid: 338), (ii) database: genomes (chromosomes from all organisms), and (iii) optional parameters: default values, except that targets that have four (not seven) or more mismatches with the primer were ignored. because draft sequences are not included as templates in primer-BLAST, the different target sequences amplified from $X$. citri pv. citri strain IAPAR 306 were also blasted against them using genomic BLAST (http://www.ncbi.nlm.nih.gov/sutils/genom_table.cgi (July 2012).

A number of mismatches were observed between the primers and some DNA templates. We relied on previous studies $(9,14)$ based on different parameters (nature, number, and position of mismatches) to predict amplifications. Single mismatches we observed were either internal or at the $3^{\prime}$-terminal base of the primer and, in this latter case, the mismatches primer:template were G:T or C:T. All these single mismatches are considered to have a minimal effect on PCR product yield. For a number of cases, several mismatches were reported between the primers and the template. Even if the efficiency of PCR can dramatically decrease in some cases, the homology and the stability of the duplex can be sufficient to lead to mispriming and misextension, resulting in at least slight signals of amplification in a standard amplification PCR protocol. We only took into account duplexes including up to three mismatches, and only considered the mismatches known to have a minimal effect on PCR yield (in this study, primer:template $=\mathrm{C}: \mathrm{A}$, $\mathrm{T}: \mathrm{C}, \mathrm{C}: \mathrm{T}, \mathrm{A}: \mathrm{C}$ or G:T) $(9,14)$.

Also, a number of DNA sequences (cloned or partial sequences) containing internal transcribed spacer (ITS), intergenic spacer

Table 1. Primer pairs used in this study

\begin{tabular}{|c|c|c|c|c|c|}
\hline Primer pairs & Sequences $\left(5^{\prime}-3^{\prime}\right)$ (upper and lower) & $\begin{array}{c}\text { Size of } \\
\text { amplicons (bp) }\end{array}$ & $\begin{array}{l}\text { Location of the } \\
\text { target sequence }\end{array}$ & Function & References \\
\hline \multirow[t]{2}{*}{$2 / 3$} & CACGGGTGCAAAAAATCT & & & & \\
\hline & TGGTGTCGTCGCTTGTAT & 224 & $\mathrm{P}$ & Unknown & 11 \\
\hline \multirow[t]{2}{*}{$4 / 7$} & TGTCGTCGCTTGTATGGC & & & & \\
\hline & GGGTGCGACCGTTCAGGA & 468 & $\mathrm{P}$ & Unknown & 12 \\
\hline \multirow[t]{2}{*}{ J-pth1/2 } & CTTCAACTCAAACGCCGGAC & & & & \\
\hline & CATCGCGCTGTTCGGGAG & 198 & $\mathrm{P}$ & $p t h \mathrm{~A}$ & 7 \\
\hline \multirow[t]{2}{*}{ J-Rxg/ J-Rxc2 } & GCGTTGAGGCTGAGACATG & & & & \\
\hline & CAAGTTGCCTCGGAGCTATC & 179 & $\mathrm{C}$ & Internal transcribed spacer & 7 \\
\hline \multirow[t]{2}{*}{ KingF/R } & TCCACTGCATCCCACATCTG & & & & \\
\hline & CAGGTGTACTGCGCTCTTCTTG & 126 & $\mathrm{C}$ & Noncoding intergenic region & 13,17 \\
\hline \multirow[t]{2}{*}{ VM3/VM4 } & GCATTTGATGACGCCATGAC & & & & \\
\hline & TCCCTGATGCCTGGAGGATA & 151 & $\mathrm{P}$ & pthA family & 17 \\
\hline \multirow[t]{2}{*}{$\mathrm{Xac01/ \textrm {Xac } 0 2}$} & CGCCATCCCCACCACCACCACGAC & & & & \\
\hline & AACCGCTCAATGCCATCCACTTCA & 582 & $\mathrm{C}$ & $r p f$ & 6 \\
\hline \multirow[t]{2}{*}{$\mathrm{XACF} / \mathrm{XACR}$} & CGTCGCAATACGATTGGAAC & & & & \\
\hline & CGGAGGCATTGTCGAAGGAA & 561 & $\mathrm{C}$ & $h r p \mathrm{~W}$ & 19 \\
\hline \multirow[t]{2}{*}{$\mathrm{XCF} / \mathrm{XCR}$} & AGGCCGGTATGCGAAAGTCCCATCA & & & & \\
\hline & CAAGTTGCCTCGGAGCTATC & 415 & $\mathrm{C}$ & Intergenic spacer region & 18 \\
\hline
\end{tabular}

a $\mathrm{P}$ : plasmid or $\mathrm{C}$ : chromosome. 
(IGS), or pthA family genes as target DNAs were automatically checked for specificity when using Primer-BLAST (July 2012). The number of these sequences varied depending on the different target regions. We found 351 accessions for ITS or IGS, representing 62 pathovars or species of Xanthomonas unrelated to X. citri. For pthA family genes, we found 54 accessions representing 10 pathovars or species of Xanthomonas unrelated to X. citri. No cloned or partial sequences including the other target regions were identified. For the primer pairs targeting ITS, IGS, and pthA family genes, we recorded the number of accessions for which an amplification was predicted according to criteria described above.

Pathogenicity tests. Pathogenicity tests of supposedly saprophytic strains were conducted on Mexican lime and Pineapple sweet orange plants using a detached leaf assay (4).

\section{Results}

Inclusivity. Pathovar citri level. Six of nine pairs of primers produced an amplicon of the expected size with all $X$. citri pv. citri strains, including pathotypes $\mathrm{A}$ and $\mathrm{A} * / \mathrm{A}^{\mathrm{w}}$. Three primer pairs (namely, 2/3, 4/7, and King) did not detect the two $\mathrm{A}^{\mathrm{w}}$ strains X2002-1035 and X2004-0010 isolated in Florida or the A* strain NCPPB 3608 from India. (Table 2). These results were fully congruent with data available for each primer pair in the respective publications (Table 2).

$C B C$-causing strains level. The two primer pairs J-pth1/2 and VM3/VM4 gave full inclusivity at the level of CBC strains by detecting all the strains of pvs. citri and aurantifolii (Table 2; Supplementary Figures S1 and S2) while all the other primers failed to detect X. citri pv. aurantifolii. All these amplification patterns are similar to those available in the original literature. The only discordant result concerned J-pth1/2. which tested negative a single $X$. citri pv. aurantifolii strain (Table 2).

Exclusivity. Tests against other xanthomonads pathogenic to citrus. None of the PCR primers used in this study produced an amplicon from the two strains of $X$. axonopodis pv. citrumelo. In contrast, all primer pairs except $\mathrm{KingF} / \mathrm{R}$ gave a positive signal with at least one of the two strains NCPPB 1759 and NCPPB 3213 of $X$. citri pv. bilvae (Tables 2). These results completely reproduced limited data previously available for these two pathovars (Table 2).

Tests against other pathogenic Xanthomonas spp. All primer pairs detected 1 (primer pair KingF/R) to 13 other pathogenic xanthomonads strains representing 1 to 10 additional pathovars or species (Tables 2). In some cases, low-intensity bands of the expected size were observed, suggesting a lower efficiency of PCR reaction, probably due to mismatches between the primers and the matrix. The phylogenetically close strains belonging to $X$. citri sensu Ah You et al. (1) (syn. X. axonopodis genetic subgroups 9.5 and 9.6) (23) were preferentially amplified by the different primer pairs. Three primer sets (J-pth1/2, VM3/4, and J-RXg/c2) detected 12 to 13 other pathogenic xanthomonads (the same ones for J-pth1/2 and VM3/4), including all the subgroup 9.5 and 9.6 strains, and, therefore, exhibited poor specificity. The comparison with previous data available in the respective publications showed that relatively more cross-reactions were observed with the exclusivity panel of strains used in this study (Table 2). Nevertheless, the results were fully consistent between the present and previous studies when comparing similar strains, pathovars, or species.

Tests against saprophytic Xanthomonas spp. All of the supposedly saprophytic Xanthomonas strains did not produce any symptoms in pathogenicity tests with two citrus species.

The primer pairs $\mathrm{XCF} / \mathrm{R}, \mathrm{XACF} / \mathrm{R}$, and $4 / 7$ did not generate any amplicons of the expected size from the 20 supposedly saprophytic Xanthomonas strains whereas all other primer pairs directed a DNA amplification of the expected size from at least one of these strains. As stated previously, a number of amplified bands were of low intensity compared with the positive control. The primer pairs King F/R and J-RXg/c2 generated amplicons with the same intensity as for positive controls for one and three saprophytic strains, respectively.

In silico analysis. Inclusivity and exclusivity performance of the primer sets were checked in silico on the sequences available in NCBI databases.

Amplicons of the expected size were obtained for each pair of primers when performing in silico amplification from the complete genome sequence of the $X$. citri pv. citri-A strain IAPAR 306. Likewise, only J-pth1/2 and VM3/VM4 were predicted to generate amplicons from the two genomic sequences of $X$. citri pv. aurantifolii strains ICPB 11122 and ICPB 10535. Although three mismatches were observed between the two J-pth $1 / 2$ primers and the template, the two consecutive mismatches A:C located at 15 and 16 bases from the $3^{\prime}$ end of J-pth1 as well as the C:T mismatch at the $3^{\prime}$ end of J-pth2 should not significantly affect amplification $(9,14)$.

In silico analysis from the 90 sequence genomes of pathogenic Xanthomonas spp. available on NCBI (Table 3) showed that $\mathrm{VM} 3 / 4, \mathrm{~J}-\mathrm{RXg} / \mathrm{c} 2,2 / 3,4 / 7, \mathrm{XCF} / \mathrm{R}, \mathrm{XACF} / \mathrm{R}$, and Xac01/02 are able to generate specific amplicons with satisfactory PCR efficiency $(0$ or 1 single mismatch between the two primers and the template) from 24 ( 3 X. oryzae pv. oryzae strains $+X$. oryzae pv. oryzicola $+X$. axonopodis pv. punicae $+X$. axonopodis pv. glycines $+X$. citri pv. mangiferaeindicae $+17 X$. axonopodis pv. manihotis), 6 ( 3 X. oryzae pv. oryzae strains $+X$. axonopodis pv. punicae $+X$. axonopodis pv. glycines $+X$. citri pv. mangiferaeind cae), 6 (X. campestris pv. vasculorum $+X$. axonopodis pv. punicae $+4 X$. axonopodis pv. manihotis), 6 (X. campestris pv. vasculorum $+X$. axonopodis pv. punicae $+4 X$. axonopodis pv. manihotis $), 3$ (X. axonopodis pv. punicae $+X$. axonopodis pv. glycines $+X$. citri pv. mangiferaeindicae), 1 (X. axonopodis pv. punicae), and 1 (X.

Table 2. Polymerase chain reaction responses of Xanthomonas spp. pathogenic on citrus and non-target Xanthomonas strains using nine primers pairs and comparison with original literature ${ }^{\mathrm{a}}$

\begin{tabular}{|c|c|c|c|c|c|c|c|c|}
\hline \multirow[b]{2}{*}{ Primer pair } & \multicolumn{3}{|c|}{$X$. citri pv. citri strains $(n=37)$} & \multirow[b]{2}{*}{$\begin{array}{c}X . \text { citri pv. } \\
\text { aurantifolii }(n=7)\end{array}$} & \multirow[b]{2}{*}{$\begin{array}{c}\text { X. alfafae pv. } \\
\text { citrumelo }(n=2)\end{array}$} & \multirow[b]{2}{*}{$\begin{array}{c}X . \text { citri pv. } \\
\text { bilvae }(n=2)\end{array}$} & \multirow[b]{2}{*}{$\begin{array}{c}\text { Other } \\
(n=19)^{b}\end{array}$} & \multirow[b]{2}{*}{$\begin{array}{l}\text { Saprophytic } \\
\quad(n=20)^{\mathbf{c}}\end{array}$} \\
\hline & $\underset{(n=22)}{\mathrm{A}}$ & $\begin{array}{c}\mathbf{A}^{*} \\
(n=13)\end{array}$ & $\begin{array}{c}\mathrm{A}^{\mathrm{w}} \\
(n=2)\end{array}$ & & & & & \\
\hline $2 / 3$ & $22(12 / 12)$ & $12(-)$ & $0(-)$ & $0(0 / 5)$ & $0(0 / 4)$ & $1(1 / 2)$ & $3(1 / 2)$ & $7(-)$ \\
\hline $4 / 7$ & $22(-)$ & $12(-)$ & $0(-)$ & $0(-)$ & $0(-)$ & $1(-)$ & $4(-)$ & $0(0 / 4)$ \\
\hline J-Pth1/2 & $22(41 / 41)$ & $13(7 / 7)$ & $2(1 / 1)$ & $7(8 / 9)$ & $0(0 / 1)$ & $1(-)$ & $13(0 / 5)$ & $4(-)$ \\
\hline $\mathrm{J}-\mathrm{Rxg} / \mathrm{c} 2$ & $22(41 / 41)$ & $13(7 / 7)$ & $2(1 / 1)$ & $0(0 / 9)$ & $0(0 / 1)$ & $2(-)$ & $12(0 / 5)$ & $6(-)$ \\
\hline KingF/R & $22(1 / 1)$ & $12(1 / 1)$ & $0(0 / 1)$ & $0(0 / 2)$ & $0(0 / 1)$ & $0(-)$ & $1(-)$ & $1(-)$ \\
\hline VM3/VM4 & $22(1 / 1)$ & $13(1 / 1)$ & $2(-)$ & $7(2 / 2)$ & $0(0 / 1)$ & $1(-)$ & $13(-)$ & $1(-)$ \\
\hline Хac01/Хac02 & $22(71 / 71)$ & $13(4 / 4)$ & $2(8 / 8)$ & $0(0 / 10)$ & $0(0 / 1)$ & $2(-)$ & $6(0 / 28)$ & $6(-)$ \\
\hline XACF/XACR & $22(2 / 2)$ & $13(-)$ & $2(-)$ & $0(0 / 1)$ & $0(-)$ & $2(-)$ & $2(0 / 16)$ & $0(-)$ \\
\hline $\mathrm{XCF} / \mathrm{XCR}$ & $22(36 / 36)$ & $13(-)$ & $2(-)$ & $0(-)$ & $0(-)$ & $2(-)$ & $8(1 / 8)$ & $0(-)$ \\
\hline
\end{tabular}

${ }^{a}$ Number of positive samples: both weak and strong signals are recorded. Numbers in parentheses indicate the positive samples out of the total number of samples tested as described in the corresponding literature (Table 1); - indicates no sample was tested by the authors. Collection strains used in original publications are partly different from the strain collection used in this study. Strains, pathovars, or species shared by the present study and previous studies are reported in Supplementary Tables S1 and S2.

${ }^{\mathrm{b}}$ Other pathogenic xanthomonads.

c Saprophytic xanthomonads isolated from citrus. 
axonopodis pv. punicae) non-target strains, respectively. KingF/R generated amplicons only from the $X$. citri pv. citri strain IAPAR 306. Some mismatches were observed with different templates, particularly for J-pth $1 / 2$, and we predicted at least weak signals of amplification from these duplexes.

The experimental PCR results obtained with the reference strains perfectly matched the prediction obtained in silico from the genome sequences (Table 3): no amplicons were produced from $X$. axonopodis pv. citrumelo strain CFBP $3138, X$. campestris $\mathrm{pv}$. campestris strain LMG 568, and $X$. euvesicatoria strain CFBP 5618 by any primer sets, whereas both primer sets $\mathrm{J}-\mathrm{RXg} / \mathrm{c} 2$ and VM3/4 produced an amplicon of the expected size from $X$. oryzae pv. oryzae strain PXO99A. Similarly, amplicons of the expected size were obtained from $X$. citri $p v$. mangiferaeindicae CFBP 1716 with $\mathrm{VM} / 3 / 4, \mathrm{~J}-\mathrm{RXg} / \mathrm{c} 2, \mathrm{XCF} / \mathrm{R}$, and J-pth1/2. In the case of $\mathrm{J}$-pth1/2, two mismatches were recorded between the primers and the template but no difference in band intensity was observed, confirming a minimal effect of some mutations on PCR yield. Conversely, a slight signal of the expected size was obtained with the primer pair J-pth1/2 from strain PXO99A, corresponding to a lower PCR efficiency due to the three mismatches observed between the two primers and the template.

In addition, primer-BLAST results from clones or partial sequences available from NCBI showed that $\mathrm{VM} 3 / 4, \mathrm{~J}-\mathrm{RXg} / \mathrm{c} 2$,

Table 3. In silico polymerase chain reaction (PCR) responses from whole-genome sequences of phytopathogenic Xanthomonas spp. ${ }^{\mathrm{a}}$

\begin{tabular}{|c|c|c|c|c|c|c|c|c|c|c|}
\hline Bacterial genomes & $\begin{array}{c}\text { GenBank } \\
\text { accessions }\end{array}$ & VM3/4 & J-pth $\mathbf{1 / 2}$ & J-RXg/c2 & $4 / 7$ & $2 / 3$ & $\mathrm{XACF} / \mathrm{R}$ & King F/R & Xac 01/02 & $\mathrm{XCF} / \mathrm{R}$ \\
\hline $\begin{array}{l}\text { Xanthomonas axonopodis } \\
\text { pv. citrumelo } \text { str. } \mathrm{F} 1\end{array}$ & СР002914.1 & - & - & - & - & - & - & - & - & - \\
\hline X. albilineans str. GPE PC73 & FP565176 & - & - & - & - & - & - & - & - & - \\
\hline X. citri pv. citri str. 306 & AE008923.1 & + & $+(1)$ & + & $+(1)$ & + & + & + & + & + \\
\hline $\begin{array}{l}\text { X. campestris pv. campestris str. } \\
\text { ATCC } 33913 \text {, str. B100, str. } 8004\end{array}$ & $\begin{array}{l}\text { AE008922.1, } \\
\text { AM920689.1, } \\
\text { CP000050.1 }\end{array}$ & - & - & - & - & - & - & - & - & - \\
\hline X. euvesicatoria str. $85-10$ & AM039952.1 & - & - & - & - & - & - & - & - & - \\
\hline $\begin{array}{l}\text { X. citri pv. aurantifolii str. ICPB } \\
10535^{\mathrm{b}}, \text { str. ICPB } 11122^{\mathrm{b}}\end{array}$ & $\begin{array}{l}\text { ACPY00000000, } \\
\text { ACPX00000000 }\end{array}$ & $+(1)$ & w (3) & - & - & - & - & - & - & - \\
\hline X. gardneri str. ATCC $19865^{\mathrm{b}}$ & AEQX00000000 & - & - & - & - & - & - & - & - & - \\
\hline $\begin{array}{l}\text { X. oryzae pv. oryzae str. PXO99A, } \\
\text { str. KACC10331, } \\
\text { str. MAFF311018 }\end{array}$ & $\begin{array}{l}\text { CP000967.1, } \\
\text { AE013598.1, } \\
\text { AP008229.1 }\end{array}$ & $+(1)$ & $\mathrm{w}(3)$ & $+(1)$ & - & - & - & - & - & - \\
\hline $\begin{array}{l}\text { X. oryzae pv. oryzae str. } \mathrm{X} 8-1 \mathrm{~A}^{\mathrm{b}} \\
\text { str. X11-5A }\end{array}$ & $\begin{array}{l}\text { AFHK00000000, } \\
\text { AFHL00000000 }\end{array}$ & - & - & w (2) & - & - & - & - & - & - \\
\hline X. perforans str. $91-118^{\mathrm{b}}$ & AEQW00000000 & - & - & - & - & - & - & - & - & - \\
\hline X. vesicatoria str. ATCC $35937^{\mathrm{b}}$ & AEQV00000000 & - & - & - & - & - & - & - & - & - \\
\hline $\begin{array}{l}X . \text { oryzae pv. oryzicola } \text { str. BLS2 } \\
X . \text { campestris py vasculorum }\end{array}$ & AAQN00000000 & $+(1)$ & $\mathrm{w}(3)$ & $\mathrm{w}(3)$ & - & - & - & - & - & - \\
\hline NCPPB $4381^{\mathrm{b}}$ and str. 'Kenyan'b & AGFQ01000000 & - & - & - & - & - & - & - & - & - \\
\hline $\begin{array}{l}\text { X. axonopodis pv. punicae } \\
\text { str. LMG } 859^{\mathrm{b}} \\
\text { X. citri pv. mangiferaeindicae } \mathrm{LMG}\end{array}$ & CAGJ00000000 & + & $\mathrm{w}(2)$ & + & + & + & + & - & $+(1)$ & + \\
\hline $\begin{array}{l}941^{\mathrm{b}}(\mathrm{CFBP} 1716) \\
\text { X. axonopodis pv. glycines }\end{array}$ & САНО00000000 & + & $\mathrm{w}(2)$ & $+(1)$ & - & - & - & - & - & + \\
\hline $\begin{array}{l}\text { str. } 12-2^{\mathrm{b}} \\
X . \text { axonopodis pv. manihotis } \\
4 \text { strains }^{\mathrm{b}}\end{array}$ & $\begin{array}{l}\text { AJJO00000000 } \\
\text { AKEW00000000- } \\
\text { AKEY00000000, } \\
\text { AKFB } 00000000\end{array}$ & + & $\mathrm{w}(2)$ & + & - & - & - & - & - & + \\
\hline $\begin{array}{l}\text { X. axonopodis pv. manihotis } \\
17 \text { strains }^{\mathrm{b}}\end{array}$ & $\begin{array}{c}\text { AKFB00000000 } \\
\text { AKCW00000000, } \\
\text { AKDA00000000, } \\
\text { AKDF00000000, } \\
\text { AKDH00000000, } \\
\text { AKDI00000000, } \\
\text { AKDN00000000, } \\
\text { AKDO00000000, } \\
\text { AKDQ00000000, } \\
\text { AKDT00000000- } \\
\text { AKDV00000000, } \\
\text { AKEF00000000, } \\
\text { AKEI00000000, } \\
\text { AKEN00000000, } \\
\text { AKES00000000, } \\
\text { AKEU00000000, }\end{array}$ & $+(1)$ & $w(3)$ & - & + & + & - & - & - & - \\
\hline $\begin{array}{l}\text { X. axonopodis pv. manihotis } \\
44 \text { strains }^{\mathrm{b}}\end{array}$ & $\begin{array}{l}\text { AKFF00000000 } \\
\text { AKCX00000000- } \\
\text { AKFI00000000 } \\
\text { except all X. } \\
\text { axonopodis pv. } \\
\text { manihotis }\end{array}$ & $+(1)$ & $\mathrm{w}(3)$ & - & - & - & - & - & - & - \\
\hline & accessions above & - & - & - & - & - & - & - & - & - \\
\hline X. campestris pv. raphani str. $756 \mathrm{C}$ & СР002789.1 & - & - & - & - & - & - & - & - & - \\
\hline
\end{tabular}

\footnotetext{
a Signal expected: + or $+(1)=$ positive signal, no or one mismatch, respectively, between the template and the primers; $-=$ negative signal, number of mismatches $\geq 4$; $w(2)$ or $(3)=$ possible weak signal, two or three mismatches between the template and the primers. Six bacterial strains in bold were tested with the different PCR assays and the results are in accordance with the prediction made in silico.

${ }^{\mathrm{b}}$ Whole-genome shotgun sequences.
} 
$\mathrm{J}-\mathrm{Pth} 1 / 2$, and $\mathrm{XCF} / \mathrm{R}$ were able to generate expected amplicons from 50, 32, 13, and 9 accessions, respectively, representing 10, 13, 8, and 4 pathogenic Xanthomonas spp. other than $X$. citri pv. citri and $X$. citri pv. aurantifolii, respectively. On the other hand, 4/7, 2/3, Xac01/02, KingF/R, and XACF/R primer pairs were predicted to direct a specific amplification only from sequences of $X$. citri pv. citri (data not shown).

\section{Discussion}

The question of the reliable detection of quarantine pathogens has been a major issue for decades. Identification and detection of a quarantine pathogen must be rapid, specific, and efficient. The aim of this study was to reevaluate the specificity of PCR-based diagnostic tools previously designed for the identification of Xanthomonas citri pv. citri or CBC-causing strains (both $X$. citri pv. citri and $X$. citri pv. aurantifolii), considering recent diversity data. The specificity was assayed with an inclusivity and exclusivity panel of strains pathogenic to citrus representative of the known current genetic diversity and nonrelated strains or close neighbors. Indeed, an important issue was to test the specificity of primers on ecologically related (i.e., sharing the same host) or genetically closed strains because it increases the possibility of cross-reactions. The primer pairs have been previously evaluated on different $X$. citri pv. citri strain collections varying from $n=2$ to $n=83$ and on different collections of non-target xanthomonads that may or may not be pathogenic to citrus. However, they had never been submitted to the same panel of bacterial strains, making impossible a precise evaluation of their inclusivity and exclusivity parameters.

The tests were performed on bacterial pure cultures as recommended by the European Standard EN ISO 16140:2003 to evaluate inclusivity and exclusivity criteria.

Inclusivity results were generally in accordance with the results already available, different levels of detection being achieved at a CBC or a pathovar level according to the different primer sets.

Only two primer pairs (J-pth1/2 and VM3/VM4) offered a full inclusivity at the CBC-causing strain level, in accordance with previous results for the latter (17). Nevertheless, J-pth1/2 primers tested negative on pv. aurantifolii strain (XC64) in the original article (7). We did not include it in our study because inoculation tests showed that our isolate was not pathogenic to $C$. aurantifolia (data not shown). These two primer pairs target a gene from the avrBs3/pthA gene family that encodes transcription activator-like effectors. Homologs of this gene were found in pv. aurantifolii but not in $X$. axonopodis pv. citrumelo, causing necrotic lesions morphologically different from canker on citrus (27).

Four sets of primers (J-RXg/c2, Xac01/Xac02, XACF/XACR, and $\mathrm{XCF} / \mathrm{XCR}$ ) were able to detect all $X$. citri pv. citri strains whereas they did not detect $X$. citri pv. aurantifolii and $X$. axonopodis pv. citrumelo strains, in accordance with previous data available in the respective publications.

However, we pointed out that three primer sets $(2 / 3,4 / 7$, and $\mathrm{KingF} / \mathrm{R}$ ) were unable to test positive some of the $X$. citri pv. citri$\mathrm{A}^{*} / \mathrm{A}^{\mathrm{w}}$ strains, as was previously shown for primers $4 / 7(4,26)$. These strains (the two $\mathrm{A}^{\mathrm{w}}$ strains and the NCPPB $3608 \mathrm{~A}^{*}$ strain) were shown to be genetically closely related and unique within the pathotype $A^{*}$ even though they originated from different areas (3).

Concerning the exclusivity, all primer pairs except KingF/R reacted positively with at least one strain of the related but distinct pv. bilvae, confirming previous results obtained for primers $2 / 3$ and $4 / 7(4,11,12)$. Moreover, whatever the primer set used, positive results with non-target strains were recorded. The possibility that these cross-reactive strains were mislabeled was very low because all the strains used in this study have been previously characterized by pathogenicity tests or molecular analyses $(1,4)$. In any case, cross-reactivity with non-target xanthomonads was expected because some of the PCRs' DNA targets are located in relatively conserved DNA regions such as ITS or pathogenicity genes such as $p t h A$, which are known to be widely present within the xanthomonads (30). Our results are congruent with previous work when testing the primer sets on the same xanthomonads strains, pathovars, or species $(6,18,19)$. Most of the non-target xanthomonads amplified in our study clustered in the same genetic groups (23) as $X$. citri pv. citri and $X$. citri pv. aurantifolii, and the apparent greater number of cross-reactions actually reflects the greater number of neighbor strains included in our study compared with the previous studies.

The analyses performed in silico using primer BLAST and genomic BLAST are consistent with these data, showing a lack of specificity for some primers, mostly for strains belonging to $X$. axonopodis genetic subgroups 9.5 and 9.6, in agreement with the results obtained in our PCR assays. Cross-reactions of the primers with Xanthomonas spp. affecting other crops should not interfere in the diagnostics of citrus canker disease because most xanthomonads have a highly restricted host range (16). In contrast, the positive reactions obtained for some saprophytic strains isolated from citrus with some primer pairs could lead to doubtful or falsepositive results, particularly in the cases where the signals were similar in intensity to that of $X$. citri pv. citri (King F/R, and $\mathrm{J}-\mathrm{RXg} / \mathrm{c} 2$ ). Indeed, all these saprophytic Xanthomonas strains have a morphology similar to $X$. citri pv. citri strains after isolation on YPGA or semiselective KC media (22).

No primer sets fully discriminated between the pathotypes A and A*. Discrimination between $X$. citri pv. citri pathotypes responsible for ACC is an interesting issue because the contamination by strains with a restricted host range limits the hosts to be investigated in terms of surveillance, control, and eradication.

The compilation of inclusivity and exclusivity data allowed us to select the primer pairs J-pth1/2 (CBC level) and XACF/R (pathovar level), which offered $100 \%$ inclusivity and a correct exclusivity performance (i.e., primers displaying no strong crossreactions with supposedly saprophytic strains and showing the lowest cross reactivity with the other non-target strains). J-pth $1 / 2$ is one of the primer pairs proposed in the EPPO standard for diagnosis of $X$. citri pv. citri which is intended for use by approved laboratory networks under the authority of National Plant Protection Organizations. We propose to use, in combination, the primer sets J-pth1/2 and XACF/R, which should react positively with all the strains of $X$. citri pathogenic to citrus listed on the EPPO list A1 and should discriminate pv. aurantifolii from pvs. citri and bilvae. Moreover, considering both responses should limit the possibility of misinterpretations due to cross-reactions with nontarget strains. In addition, in the absence of canker symptoms, amplicons produced by the primers XACF/XACR from rutaceous plant samples could suggest the presence of $X$. citri pv. bilvae.

The data presented here allow a thorough comparison of PCR protocols, which is difficult to achieve from bibliographic references because of the marked differences in the strain collections used in the original articles. The diagnostic tests should be periodically reevaluated due to the appearance and description of new strains. Analyses performed in silico from public databases, such as NCBI, can also be very informative and should be performed, especially because an increasing number of sequences are now available. These results showed that there is still a need for highly specific PCR-based diagnostic tools for X. citri pv. citri. Moreover, whatever the constraints of phytosanitary legislation, pathotype discriminative primers would be useful to discriminate very closely related strains with a different host spectrum to facilitate the global or local epidemiological surveillance of this pathogen. The development of next-generation sequencing should facilitate the rapid development of diagnostic markers in the near future (15); in particular, current sequencing projects concerning $X$. citri pv. citri (XanthoScope;

http://www.genoscope.cns.fr/agc/microscope/home/index.php) should be useful to develop new diagnostic tools for this bacterium.

\section{Acknowledgments}

This research was funded by the European Union (POSEIDOM, European Regional Development Fund), the French Ministry of Agriculture, the Conseil Régional de La Reunion, and CIRAD. We thank A. Moreau and V. Maillot for their technical assistance. 


\section{Literature Cited}

1. Ah-You, N., Gagnevin, L., Grimont, P. A. D., Brisse, S., Nesme, X., Chiroleu, F., Bui Thi Ngoc, L., Jouen, E., Lefeuvre, P., Vernière, C., and Pruvost, O. 2009. Polyphasic characterization of xanthomonads pathogenic to Anacardiaceae and their relatedness to different Xanthomonas species. Int. J. Syst. Evol. Microbiol. 59:306-318.

2. Brunings, A. M., and Gabriel, D. W. 2003. Xanthomonas citri: breaking the surface. Mol. Plant Pathol. 4:141-157.

3. Bui Thi Ngoc, L., Vernière, C., Jarne, P., Brisse, S., Guérin, F., Boutry, S., Gagnevin, L., and Pruvost, O. 2009. From local surveys to global surveillance: three high throughput genotyping methods for the epidemiological monitoring of Xanthomonas citri pv. citri pathotypes. Appl. Environ. Microbiol. 75:1173-1184

4. Bui Thi Ngoc, L., Vernière, C., Jouen, E., Ah-You, N., Lefeuvre, P., Chiroleu, F., Gagnevin, L., and Pruvost, O. 2010. Amplified fragment length polymorphism and multilocus sequence analysis-based genotypic relatedness among pathogenic variants of Xanthomonas citri pv. citri and Xanthomonas campestris pv. bilvae. Int. J. Syst. Evol. Microbiol. 60:515-525.

5. Bui Thi Ngoc, L., Vernière, C., Pruvost, O., Kositcharoenkul, N., and Phawichit, S. 2007. First report in Thailand of Xanthomonas axonopodis pv. citri-A* causing citrus canker on lime. Plant Dis. 91:771.

6. Coletta-Filho, H. D., Takita, M. A., De Souza, A. A., Neto, J. R., Destéfano, S. A. L., Hartung, J. S., and Machado, M. A. 2006. Primers based on the $r p f$ gene region provide improved detection of Xanthomonas axonopodis pv. citri in naturally and artificially infected citrus plants. J. Appl. Microbiol. 100:279-285.

7. Cubero, J., and Graham, J. H. 2002. Genetic relationship among worldwide strains of Xanthomonas causing canker in citrus species and design of new primers for their identification by PCR. Appl. Environ. Microbiol. 68:12571264.

8. Derso, E., Vernière, C., and Pruvost, O. 2009. First report of Xanthomonas citri pv. citri-A* causing citrus canker on lime in Ethiopia. Plant Dis. 93:203.

9. Goodman, M. F. 1995. DNA polymerase fidelity: misinsertions and mismatched extensions. Pages 17-31 in: PCR strategies. M. A. Innis, Gelfand, D. H., and Sninsky, J. J., eds. Academic Press, San Diego, CA.

10. Gottwald, T. R., Hughes, G., Graham, J. H., Sun, X., and Riley, T. 2001. The citrus canker epidemic in Florida: The scientific basis of regulatory eradication policy for an invasive species. Phytopathology 91:30-34.

11. Hartung, J. S., Daniel, J. F., and Pruvost, O. P. 1993. Detection of Xanthomonas campestris pv. citri by the polymerase chain reaction method. Appl. Environ. Microbiol. 59:1143-1148.

12. Hartung, J. S., Pruvost, O. P., Villemot, I., and Alvarez, A. 1996. Rapid and sensitive colorimetric detection of Xanthomonas axonopodis pv. citri by immunocapture and a nested-polymerase chain reaction assay. Phytopathology $86: 95-101$

13. Kingsley, M. T., and Fritz, L. K. 2000. Identification of the citrus canker pathogen Xanthomonas axonopodis pv. citri A by fluorescent PCR assays. (Abstr.) Phytopathology 90:S42.

14. Kwok, S., Kellogg, D. E., McKinney, N., Spasic, D., Goda, L., Levenson, C., and Sninsky, J. J. 1990. Effects of primer-template mismatches on the polymerase chain reaction: human immunodeficiency virus type 1 model studies. Nucleic Acids Res. 18:999-1005.

15. Lang, J. M., Hamilton, J. P., Diaz, M. G. Q., Van Sluys, M. A., Burgos, M. R. G., Vera Cruz, C. M., Buell, C. R., Tisserat, N. A., and Leach, J. E. 2010. Genomics-based diagnostic marker development for Xanthomonas oryzae pv. oryzae and X. oryzae pv. oryzicola. Plant Dis. 94:311-319.

16. Leyns, F., De Cleene, M., Swings, J. G., and De Ley, J. 1984. The host range of the genus Xanthomonas. Bot. Rev. 50:308-356.

17. Mavrodieva, V., Levy, L., and Gabriel, D. W. 2004. Improved sampling methods for real-time polymerase chain reaction diagnosis of citrus canker from field samples. Phytopathology 94:61-68.

18. Miyoshi, T., Sawada, H., Tachibana, Y., and Matsuda, I. 1998. Detection of Xanthomonas campestris pv. citri by PCR using primers from the spacer region between the 16S and 23S rRNA genes. Ann. Phytopathol. Soc. Jpn. 64:249-254.

19. Park, D. S., Hyun, J. W., Park, Y. J., Kim, J. S., Kang, H. W., Hahn, J. H. and Go, S. J. 2006. Sensitive and specific detection of Xanthomonas axonopodis pv. citri by PCR using pathovar specific primers based on hrpW gene sequences. Microbiol. Res. 161:145-149.

20. Parnell, S., Gottwald, T. R., van ven Bosch, F., and Gilligan, C. A. 2009 Optimal strategies for the eradication of Asiatic citrus canker in heterogeneous host landscapes. Phytopathology 99:1370-1376.

21. Patel, M. K., Allayyanavaramath, S. B., and Kulkarni, Y. S. 1953. Bacterial shot-hole and fruit canker of Aegle marmelos Correa. Curr. Sci. 22:216-217.

22. Pruvost, O., Roumagnac, P., Gaube, C., Chiroleu, F., and Gagnevin, L. 2005. New media for the semi-selective isolation and enumeration of Xanthomonas campestris pv. mangiferaeindicae, the causal agent of mango bacterial black spot. J. Appl. Microbiol. 99:803-815.

23. Rademaker, J. L. W., Louws, F. J., Schultz, M. H., Rossbach, U., Vauterin, L., Swings, J., and De Bruijn, F. J. 2005. A comprehensive species to strain taxonomic framework for Xanthomonas. Phytopathology 95:1098-1111.

24. Schaad, N. W., Postnikova, E., Lacy, G. H., Sechler, A., Agarkova, I., Stromberg, P. E., Stromberg, V. K., and Vidaver, A. K. 2006. Emended classification of xanthomonad pathogens on citrus. Syst. Appl. Microbiol. 29:690-695.

25. Schoulties, C. L., Civerolo, E. L., Miller, J. W., Stall, R. E., Krass, C. J., Poe, S. R., and Ducharme, E. P. 1987. Citrus canker in Florida. Plant Dis 71:388-395.

26. Sun, X. A., Stall, R. E., Jones, J. B., Cubero, J., Gottwald, T. R., Graham, J. H., Dixon, W. N., Schubert, T. S., Chaloux, P. H., Stromberg, V. K., Lacy, G. H., and Sutton, B. D. 2004. Detection and characterization of a new strain of citrus canker bacteria from key Mexican lime and Alemow in South Florida. Plant Dis. 88:1179-1188.

27. Swarup, S., Yang, Y., Kingsley, M. T., and Gabriel, D. W. 1992. A Xanthomonas citri pathogenicity gene, pthA, pleiotropically encodes gratuitous avirulence on nonhosts. Mol. Plant-Microbe Interact. 5:204-213.

28. Vauterin, L., Hoste, B., Kersters, K., and Swings, J. 1995. Reclassification of Xanthomonas. Int. J. Syst. Bacteriol. 45:472-489.

29. Vernière, C., Hartung, J. S., Pruvost, O. P., Civerolo, E. L., Alvarez, A. M., Maestri, P., and Luisetti, J. 1998. Characterization of phenotypically distinct strains of Xanthomonas axonopodis pv. citri from Southwest Asia. Eur. J. Plant Pathol. 104:477-487.

30. White, F. W., Potnis, N., Jones, J. B., and Koebnik, R. 2009. The type III effectors of Xanthomonas. Mol. Plant Pathol. 10:749-766. 